\title{
Concepts and Roles of Faculty in the Palestinian Universities in the Light of Knowledge Economy
}

\author{
Ahlam Mustafa Hasan Awajneh ${ }^{1, *}$, Suhair Sulaiman Mohammed Sabbah² \& Inas Aref Saleh Naser ${ }^{3}$ \\ ${ }^{1}$ Department of Economics, Faculty of Business and Economy, Al-Quds University, P.O. Box: 51000. East \\ Jerusalem-Abu Dies, Palestine \\ ${ }^{2}$ Department of Psychology, Faculty of Educational Sciences, Al-Quds University, P.O. Box: $51000 . \quad$ East \\ Jerusalem-Abu Dies, Palestine \\ ${ }^{3}$ Department of Curriculum and Instruction, Faculty of Educational Sciences, Al-Quds University, P.O. Box: 51000. \\ East Jerusalem-Abu Dies, Palestine \\ *Correspondence: Department of Economics, Faculty of Business and Economy, Al-Quds University, P.O. Box: \\ 51000. East Jerusalem-Abu Dies, Palestine. E-mail: ahlamhamaideh@staff.alquds.edu
}

Received: November 14, 2017

Accepted: December 4, 2017 Online Published: December 23, 2017

doi:10.5430/wje.v7n6p80

URL: https://doi.org/10.5430/wje.v7n6p80

\begin{abstract}
The study aims to recognizing the concepts of knowledge economy and the roles of faculty members in the light of knowledge economy from the perspectives of its members, it was clear that the concept of the knowledge economy was high, it was (2.7,) and there were differences in years of experience in favor of (1-5 years) class, and in favor of the associate teacher in the educational degree, and the university in favor of Bier Ziet University. Whereas the mean of the faculty members' roles was (2.26) with differences in gender in favor of the females and as for the university, in was in favor of Bier Ziet University.
\end{abstract}

Keywords: concepts of knowledge economy; roles of faculty members in the light of knowledge economy; Palestine

\section{Introduction}

Higher education has an important role in developing communities and their economy, as it contributes in establishing, producing and disseminating new knowledge through teaching, scientific research and development. The educational institutions also play key role in preparing and creating human capital which based on job market and in a community of knowledge-based economy on it (Arab Knowledge Index, 2015).

It is considered the main core to enter into knowledge age and developing scientific research further to enhancing innovation, information technology, telecommunication, continuing education and community partnership, it is also one of important pillars of high education (Connell, 2015 \& Jum'a, 2009), so it is necessity to take in consideration the transition of Arabic universities in general and Palestinian ones in particular from their traditional role in knowledge economy age in order to get their effective participation in their entering into the knowledge economy age, this what was explained by UNISCO report (2015) which indicated to the transition of educational system towards the knowledge in information and globalization age to achieve the four purposes of that were agreed by the drafters of the report as follow: "learn to know - learn to learn - learn to be - learn to share the others". Therefore, the knowledge that individual acquires in school or university becomes no longer sufficient by itself to insure joining job market and staying as it was before, and it rapidly becomes irrelevant to keep up with the requirements of knowledge age (Abu Al-Humos, 2006).

The importance of education in general and university education in particular focuses on enabling the teacher and student to cope with a changeable knowledge environment (Abu Al-Humos, 2006) in order to increase the services of high educational institutions' role that lead to knowledge and development, focusing on ascertaining their quality and outcomes is the way to their modern role in bringing out development, progressing and tackling challenges (Ahmad, 2016). High education is considered as one of the pillars of internal qualification of any economy and an increase of the competitiveness of the countries according to the Global Arabic competiveness Report in 2013(Arab Knowledge Index, 2015). Under the challenges of the knowledge community to set out a mechanism in order to call 
on the countries of the Arabic World to scale up investment in high education and continuing education, it promotes the initiatives that aim to build knowledge-based economy and expanding the linking between universities, libraries and Arabic electronic research institutions, in addition to the increase of Arabic universities capacity in producing knowledge and deploying it and not be limit its role on consuming it, restricting the actual needs of job market and to include the curricula into the high and continuing education to gain trainings that fit job market in order to raise the graduates' levels and qualifying them for competition (Mohammad, 2012 \& Nehme, 2016).

Knowledge economy is described with knowledge explosion - acceleration - technology development - reducing geographical barriers and competition - investing in scientific research - the increase in knowledge components and the diminishing in the physical components (Abu Al-Humos, 2006).

Al-momany et al. (2010) conducted a study on the extent of the use of teaching skills based on the knowledge economy of the teachers of the Faculty of Physical Education at Yarmouk University. The results showed that the areas covered by the study on the knowledge economy came in the order (field of classroom interaction, field of planning and preparation of the lesson, field of study), and the study of the knowledge economy based on the cognitive economy of the teachers of the Faculty of Physical Education at Yarmouk University. Developing the personal qualities and skills of the learner, and finally the field of methods and methods.

The role of the university teacher is defined in the light of knowledge economy procedurally as: "Teacher's performance for the new tasks and strategies in the light of knowledge economy is more effective in preparing and planning for education, Teachers will initiate thinking of what students should know and what can be done, as a result the teacher becomes a critical practitioner, who avoids memorization, he is cooperative with his colleagues, and uses relevant multiple teaching aids (Abu Naier et al., 2011). The desired teacher in knowledge age must have two basic skills in the same time, they are: The profound scientific specialization and the psychological and educational qualification of teaching and the supervision on students. Furthermore, the teacher in knowledge age must have the following characteristics according to (Abu Al-Humos, Arabic Human Development Report, 2003; Al-Hashmi \& Al-Izawi, 2009): He should be a new knowledge resource for the student, and able to guide his students to the knowledge resources in the immediate environment of the school and in community and all over the world. He should be able to help the students, even normal or disabled student, to create cognitive and social skills that are necessary in the twenty first century, such as accessibility and problem analysis, using information to build scientific trend and view towards an issue, phoneme or problem, as well as understanding his culture, maintaining it and understanding its new elements. In the same time, understanding world culture and its terms, and dealing with it positively without intolerance or bias, in other words, keeping its cultural identity and the accessibility to the world culture in the same time. Moreover, he should know the new educational techniques, including using computer and data and information analysis techniques. The teacher should be social and scientific ideal for his students, facilitator of gaining the knowledge, responsible for the comprehensive growth of the students, model teacher and counselor.

Therefore, the university teacher needs university environment distinguishes with promoting the initiatives that aim to build knowledge-based economy and the necessity of expanding in linking the universities, libraries and Arabic research institutions electronically. It also leads to an increase in the Arabic universities' capacity in producing knowledge, deploying it and not restricting its role to consuming it. It was asserted to restrict the actual needs of job market and include the curricula in high and continuing education to get trainings that are relevant to enhance graduates' levels and qualifying them for competition (Mohammed, 2012). That is because of the important role that high education institutions play in entering into knowledge age and to achieve growth and sustainable development which was asserted by Salem (Salem, 2014).

Malika krishnaswam (2015) implemented a study from knowledge traditional to knowledge economy: positive interludes in Indian higher education, this study trace the roots of Indian education in general and higher education, in particular through the ages and the changes brought about with and without the involvement of the state.

In Palestine particularly, high education faced enormous challenges in confronting obstacles that have been being made by Israeli occupation since 1967, what takes in consideration the political, social and economic conditions, and this was explained by Al-Najar (Al-Najar, 2012), high education is one of the supporting pillars of the Palestinian knowledge economy community provided it fits the age, modernity and technology trends, Agha and Abu Al-Khier (Agha \& Abu Al-Khier, 2012) demonstrated that the requirements of transition towards knowledge economy from universities' leaderships in Palestine are research and knowledge requirements with ratio up to $(67.8 \%)$ followed with the requirements that related to educational policy $(66.3 \%)$ and finally the physical requirements $(62.5 \%)$ regardless to scientific degree.

The researchers (Assabah, Nasir \& Moustafa, 2016) conducted three studies on the teacher and knowledge economy 
that form a challenge in both general and high education to keep up with development and global progress in order to build Arabic beacon in this field.

It was found that teachers have practiced their roles and principles clearly (of the concepts) of knowledge economy in the following areas (planning, performing teaching, self-development, students teaching), especially the new teachers in teaching whose years of experiences less than 5 years. The results of group and individual interviews also indicated that some of knowledge economy principles that are practiced by teachers are centered at teaching strategies and on teacher's role, and there is principles that are not practiced by teachers specially in research and social communication fields in addition to student's role in producing knowledge and in realistic evaluation field.

From the perspective of the educational supervisors about teacher's awareness of their roles, it was explained that the teacher performs his role but moderately, and teachers need training in the new roles in knowledge economy age, which is the most important of his role as a researcher, unique and untypical, creative and criticizer.

\subsection{Questions of the Study}

Al-Najar (2012) demonstrated that the horizontal expansion in the Palestinian universities and middle colleges was a response to the increase of need not of quality, knowledge community forms a challenge for the Palestinians and all the developing countries, in addition, high education is one of the supporting pillars of the knowledge economy community provided that it fits the trends of modernity and technology, as the researchers believe in the importance of the faculty members' role in enhancing education level in universities and activating their roles in entering into knowledge age, in this study, they sought to explain the concepts and roles of teachers in the light of knowledge economy from the perspective of faculty members in the Palestinian universities.

This study tries to answer the following questions:

1- What is "knowledge economy concept" from the perspective of faculty members at the Palestinian universities?

2- Are there statistically significant differences at the level $(\propto \leq 0.05)$ in the sample participants' responses about the knowledge economy concept due to gender, college, years of experience, educational degree and university?

3- What are the roles of faculty members in the light of knowledge economy from the perspective of faculty members at the Palestinian universities?

4- Are there statistically significant differences at the level $(\propto \leq 0.05)$ in the sample participants' responses about their roles in the light of knowledge economy due to gender, college, and years of experience, educational degree and university?

\subsection{Objectives of the Study}

The study tries to achieve the following goals:

1- Recognizing the knowledge economy concept from the perspective of faculty members at the Palestinian universities.

2- Recognizing the statistically significant differences in faculty members' responses about the knowledge economy concept which is attributed to the variables of (gender, college, years of experience, educational degree and university).

3- Recognizing the teacher's roles in the light of knowledge economy from the perspective of the faculty members at the Palestinian universities.

4- Recognizing the statistically significant differences in faculty members' responses in the light of knowledge economy which are attributed to the variables of (gender, college, and years of experience, educational degree and university).

\subsection{Significance of the Study}

The study is considered significant for the following reasons:

1. Revealing the faculty members' perception of knowledge economy concept in the Palestinian universities.

2. Highlighting the roles of faculty members in high education in the light of knowledge economy. 
3. Identifying the differences in the responses of the participants about knowledge economy concept and the faculty members' roles that are attributed to the variables of (gender, college, and years of experience, educational degree and university).

4. The outcomes of the study show that there is an effort done to work on suggesting some special policies of a faculty member in the university education with an aim of entering into knowledge economy age.

5. Achieving some suggestions that contribute in activating the role of high education institutions in entering into knowledge community.

\subsection{Limitations of the Study}

The study is restricted to the sample and instruments used in it; while the study methodology is the period of time that the study was conducted in.

\section{Methods and Procedures}

The analytical and descriptive approach was used because of its appropriateness to this type of study.

\subsection{Population and Sample}

The population of the study consisted of all the faculty members in the Palestinian universities (governmental, general and private) in the West Bank. The number is estimated to (6525) faculty members (Palestinian Central Bureau of Statistics, Statistics of High Education, 2015-2016). The sample included together up to (201) i.e. with a ratio of approximately (3\%). Table (1) shows the distribution of the sample according to its independent variables.

Table 1. The Distribution of the Participants in the Sample of the Study According to the Variables of the Study

\begin{tabular}{cccc}
\hline Variable & Category & Number & Percentage \\
\hline Gender & Male & 120 & $\% 59.7$ \\
& Female & 81 & $\% 40.3$ \\
University & Jerusalem & 91 & $\% 45.2$ \\
& Hebron & 68 & $\% 33.8$ \\
& Bier Ziet & 20 & $\% 10$ \\
Years of experience & Bethlehem & 22 & $\% 11$ \\
& $1-5$ & 45 & $\% 22.4$ \\
& $5-10$ & 56 & $\% 27.9$ \\
& $10-15$ & 44 & $\% 21.9$ \\
Educational degree & More than 15 & 56 & $\% 27.8$ \\
& Teacher & 55 & $\% 31.3$ \\
& Assistant Professor & 63 & $\% 13.4$ \\
& Associated Professor & 27 & $\% 6$ \\
& Professor & 12 & $\% 57.2$ \\
College & Lecturer & 44 & $\% 42.8$ \\
& Scientific & 115 & $100 \%$ \\
\hline
\end{tabular}

\subsection{Instruments of the Study}

2.2.1 First: Tow-part questionnaire, they are:

\section{Knowledge economy concept and the roles of teacher in the light of knowledge economy.}

After exploring the instruments that were used in the study of Moustafa and Al-Keelani (2011), the study of Al-anasheri (2014) and the study of Abu Naer and his colleagues (Abu Naer \& et al., 2011), to check the educational literary that is related to the theme of the study and its goals and hypotheses. A special questionnaire was developed to recognize the knowledge economy concepts from the perspective of faculty members in the Palestinian universities, the instrument consisted of the finalization from the primary data of all the examined participants in each sample of the researched teachers. There were (13) items that measure knowledge economy concepts and (21) items that measure the roles of the teacher. 


\section{Checking the questionnaire:}

Likert tri-Scale (agree, neutral, disagree) was used in this study and responses $(1,2,3)$ respectively were given one score. This tri-ranking was implemented on all the items of the instrument in the study as they were considered positive items.

\section{Reliability of the two instruments:}

The reliability of the two instruments in the recent study was ascertained by presenting them on a number of professional arbitrators in education and psychology, there was agreement on the two questionnaires' validity and legibility in the light of the theoretical framework that the two instruments were built on its basis, as it was rendered of the arbitrators' honesty.

\section{Stability of the two instruments:}

The stability of the two instruments of this study was ascertained by examining the internal consistency between the items of the instruments through calculating Cronbach Alpha coefficient as the stability value of the concept instrument was (0.86) whereas the stability value of the role instrument was $(0.90)$, thus they had high degree of stability.

\subsection{Statistical Analysis}

The essential statistical treatment of data was conducted, descriptive statistics was used by calculating numbers, percentages, means, and standard deviations of the participants' responses, t-test, one - way anova analysis and Scheffe test. Stability coefficient "Cronbach Alpha" was used to weight the instrument stability using SPSS program. Table (2) shows the criterion that was used to judge the concepts and teacher's roles in the light of knowledge economy from the perspective of faculty members in the Palestinian universities.

The criterion that was used to judge the concepts and teacher's roles in the light of knowledge economy from the perspective of faculty members in the Palestinian universities in low degree $(1-1.66)$, moderate degree $(1.67-2.33)$ and high degree $(2.34-3)$.

\section{Results and Discussion}

First: Results related to the first question: What is "knowledge economy concept" from the perspective of faculty members at the Palestinian universities?

To know the knowledge economy concept in faculty members in the Palestinian universities, means and standard deviations were calculated as it is shown in the following table.

Table 2. Means and Standard Deviations of the Participants' Responses About the Knowledge Economy Concept

\begin{tabular}{|c|c|c|c|c|}
\hline No. & Item & $\mathbf{M}$ & SD & Degree \\
\hline 1 & Human is the knowledge capital. & 2.89 & 0.30 & High \\
\hline 2 & $\begin{array}{l}\text { Deployment of knowledge and its production and recruiting it efficiently in all fields of } \\
\text { social, economic and political activity. }\end{array}$ & 2.79 & 0.40 & High \\
\hline 3 & Taking use of rich informational services and developing technological applications. & 2.85 & 0.37 & High \\
\hline 4 & $\begin{array}{l}\text { The economy that discusses gaining knowledge, participating in it and using it with aim of } \\
\text { improving life quality in all fields. }\end{array}$ & 2.72 & 0.49 & High \\
\hline 5 & Equal and fair distribution of the human abilities. & 2.58 & 0.56 & High \\
\hline 6 & Developing human resources and creating sustainable development. & 2.79 & 0.43 & High \\
\hline 7 & $\begin{array}{l}\text { Educational system based on technical aids and scientific research to take use of the } \\
\text { individual's abilities in different ages. }\end{array}$ & 2.70 & 0.52 & High \\
\hline 8 & Linking education with training & 2.49 & 0.67 & High \\
\hline 9 & Economy that knowledge meets the largest part of the added- value. & 2.63 & 0.55 & High \\
\hline 10 & Deeper new understanding to the role of knowledge and human capital. & 2.67 & 0.55 & High \\
\hline 11 & $\begin{array}{l}\text { Internationality of knowledge and focusing on learning because of its importance in } \\
\text { producing knowledge. }\end{array}$ & 2.67 & 0.51 & High \\
\hline 12 & Based on producing educated individuals lifelong. & 2.86 & 0.36 & High \\
\hline 13 & $\begin{array}{l}\text { Everything that related to economics of knowledge processes itself, i.e. producing and } \\
\text { building up research and development processes. }\end{array}$ & 2.53 & 0.65 & High \\
\hline & Total scores & 2.70 & 0.31 & High \\
\hline
\end{tabular}


Table (2) reveals that the mean of knowledge economy concept in faculty members in the Palestinian universities was about (2.70) with a standard deviation $(0.31)$, which indicates that there was high degree of knowledge economy concept in faculty members in the Palestinian universities.

Second: Results related to the second question: Are there statistically significant differences at the level $(\propto \leq 0.05)$ in the sample participants' responses about the knowledge economy concept due to gender, college, and years of experience, educational degree and university?

To answer this question, means and standard deviations of the study participants' responses about the instrument in the light of the variables of this study were measured, that was as the following:

\section{The variables of gender and college, $t$-test was used to measure these variables. Table (4) explains that.}

Table 3. T-Test Results of the Differences in the Total Means Attributed to the Variables of Gender and College

\begin{tabular}{|c|c|c|c|c|c|c|c|c|c|}
\hline & \multicolumn{5}{|c|}{ Gender } & \multicolumn{4}{|c|}{ College } \\
\hline & $\mathbf{M}$ & SD & $\begin{array}{c}\text { Accounted } \\
\mathrm{T} \\
\end{array}$ & $\begin{array}{c}\text { Significance } \\
\text { level }\end{array}$ & & $\mathbf{M}$ & SD & Accounted T & $\begin{array}{c}\begin{array}{c}\text { Significance } \\
\text { level }\end{array} \\
\end{array}$ \\
\hline Male & 2.67 & 0.356 & 1.37 & 0.172 & Scientific & 2.71 & 0.364 & 0.25 & 0.798 \\
\hline Female & 2.73 & 0.231 & & & Literary & 2.70 & 0.220 & & \\
\hline
\end{tabular}

* At significance level $(\propto \leq 0.05)$

Table (4) demonstrates that there were no differences between the means of the knowledge economy concept in faculty members in the Palestinian universities due to the two variables of gender and college.

\section{Years of experience, educational degree and university variables, and means were calculated and the One - Way Analysis of Variance was conducted. Table (4) shows that:}

Table 4. The results of the One - Way Analysis of Variance to the differences in the means of the knowledge economy concept attributed to the years of experience, educational degree and university variables

\begin{tabular}{|c|c|c|c|c|c|c|c|c|c|c|c|c|}
\hline \multirow[t]{2}{*}{$\begin{array}{c}\text { Years of } \\
\text { experience }\end{array}$} & \multicolumn{2}{|c|}{$1-5$ years } & \multicolumn{2}{|c|}{$5-10$ years } & \multicolumn{2}{|c|}{$10-15$ years } & \multicolumn{2}{|c|}{$\begin{array}{c}\text { More than } 15 \\
\text { years }\end{array}$} & & & \multirow[t]{2}{*}{ F- value } & \multirow[t]{2}{*}{$\begin{array}{c}\begin{array}{c}\text { Significance } \\
\text { level }\end{array} \\
\end{array}$} \\
\hline & $\mathbf{M}$ & SD & M & SD & $\mathbf{M}$ & SD & M & SD & $\mathbf{M}$ & SD & & \\
\hline & 2.85 & 0.427 & 2.59 & 0.249 & 2.66 & 0.256 & 2.71 & 0.254 & & & 6.53 & $* 0.0001$ \\
\hline \multirow[t]{2}{*}{$\begin{array}{c}\text { Educational } \\
\text { Degree }\end{array}$} & \multicolumn{2}{|c|}{ Teacher } & \multicolumn{2}{|c|}{$\begin{array}{l}\text { Assistant } \\
\text { Professor }\end{array}$} & \multicolumn{2}{|c|}{$\begin{array}{l}\text { Associate } \\
\text { Professor }\end{array}$} & \multicolumn{2}{|c|}{ Professor } & \multicolumn{2}{|c|}{ Lecturer } & & \\
\hline & 2.79 & 0.39 & 2.73 & 0.25 & 2.67 & 0.28 & 2.44 & 0.28 & 2.61 & 0.25 & 4.64 & 0.001 \\
\hline \multirow[t]{2}{*}{ University } & \multicolumn{2}{|c|}{ Jerusalem } & \multicolumn{2}{|c|}{ Hebron } & & ier Ziet & \multicolumn{2}{|c|}{ Bethlehem } & & & & \\
\hline & 2.74 & 0.249 & 2.69 & 0.415 & 2.79 & 0.151 & 2.47 & 0.159 & & & 3.95 & $* 0.004$ \\
\hline
\end{tabular}

* At significance level $(\propto \leq 0.05)$

It is clear from table (4) that:

There was difference in the means of knowledge economy concept according to the years of experience variable. To check this difference, One - Way Analysis of Variance and Scheffe test were conducted, they revealed that there were differences in years of experience in favor of (1-5 years) class.

There were significant differences in the means of educational degree variable. To examine theses differences, One Way Analysis of Variance was conducted which found statistically significant differences, in addition to calculating Scheffe test which indicated that there were differences in favor of the Associate Professor.

There were significant differences in the means university variable. To examine theses differences, One - Way Analysis of Variance and Scheffe test were conducted which demonstrated statistically significant differences in favor of Bier Ziet University.

Third: Results related to third question: What are the roles of faculty members in the light of knowledge economy from the perspective of faculty members at the Palestinian universities? 
Means were calculated to recognize the faculty members' roles in the light of knowledge economy from their perspective in the Palestinian universities as it shown in table (5).

Table 5. Means and Standard Deviations of the Participants' Responses about the Faculty Members' Roles in the Light of Knowledge Economy

\begin{tabular}{clccc}
\hline No. & \multicolumn{1}{c}{ Item } & M & SD & Degree \\
\hline $\mathbf{1}$ & Has willingness to social work & $\mathbf{2 . 1 6}$ & $\mathbf{0 . 5 9}$ & Moderate \\
$\mathbf{2}$ & Able to negotiate and discuss learning & $\mathbf{2 . 2 2}$ & $\mathbf{0 . 5 0}$ & Moderate \\
$\mathbf{3}$ & Has skills of leading the class & $\mathbf{2 . 2 8}$ & $\mathbf{0 . 4 2}$ & Moderate \\
$\mathbf{4}$ & Has skills of justices and equality & $\mathbf{2 . 2 1}$ & $\mathbf{0 . 4 9}$ & Moderate \\
$\mathbf{5}$ & Practices the critical thinking & $\mathbf{2 . 1 9}$ & $\mathbf{0 . 5 0}$ & Moderate \\
$\mathbf{6}$ & A friend and supporter of the student & $\mathbf{2 . 2 5}$ & $\mathbf{0 . 4 8}$ & Moderate \\
$\mathbf{7}$ & Facilitator of learning & $\mathbf{2 . 2 5}$ & $\mathbf{0 . 4 8}$ & Moderate \\
$\mathbf{8}$ & Leader and creative & $\mathbf{2 . 3 3}$ & $\mathbf{0 . 4 1}$ & High \\
$\mathbf{9}$ & Model and ideal & $\mathbf{2 . 2 8}$ & $\mathbf{0 . 4 5}$ & Moderate \\
$\mathbf{1 0}$ & planner & $\mathbf{2 . 2 7}$ & $\mathbf{0 . 4 6}$ & Moderate \\
$\mathbf{1 1}$ & Has developing academic qualifications and skills & $\mathbf{2 . 3 3}$ & $\mathbf{0 . 4 2}$ & High \\
$\mathbf{1 2}$ & Has skills of innovation and challenging & $\mathbf{2 . 3 4}$ & $\mathbf{0 . 3 9}$ & High \\
$\mathbf{1 3}$ & Monitor and guider of learning & $\mathbf{2 . 2 7}$ & $\mathbf{0 . 4 4}$ & Moderate \\
$\mathbf{1 4}$ & Educator and transformer of the civilization and moral & $\mathbf{2 . 2 1}$ & $\mathbf{0 . 5 0}$ & Moderate \\
& values & & & \\
$\mathbf{1 5}$ & Able to learn by himself comprehensively & $\mathbf{2 . 0 8}$ & $\mathbf{0 . 5 4}$ & Moderate \\
$\mathbf{1 6}$ & Unique teacher and untypical & $\mathbf{2 . 2 8}$ & $\mathbf{0 . 4 5}$ & Moderate \\
$\mathbf{1 7}$ & Has high-end emotional characteristics & $\mathbf{1 . 9 8}$ & $\mathbf{0 . 6 7}$ & Moderate \\
$\mathbf{1 8}$ & Deals with his disagreement with others as source of & $\mathbf{2 . 1 6}$ & $\mathbf{0 . 5 4}$ & Moderate \\
& knowledge wealth & & & \\
$\mathbf{1 9}$ & Informational technical advisor & $\mathbf{2 . 1 9}$ & $\mathbf{0 . 4 8}$ & Moderate \\
$\mathbf{2 0}$ & Researcher & $\mathbf{2 . 1 1}$ & $\mathbf{0 . 5 5}$ & Moderate \\
$\mathbf{2 1}$ & Cooperative with his colleagues & $\mathbf{2 . 2 2}$ & $\mathbf{0 . 4 7}$ & Moderate \\
& & $\mathbf{2 . 2 2}$ & $\mathbf{0 . 2 4}$ & Moderate \\
\hline
\end{tabular}

The table reveals that faculty members' roles in the light of knowledge economy from their perspective in the Palestinian universities were moderate as it was (2.26) with a standard deviation (0.24). This indicates that they have the roles of teacher in the light of the knowledge economy but those roles need to be developed to enhance the criteria of knowledge economy.

Fourth: Results related to the fourth question: Are there statistically significant differences at the level $(\propto \leq 0.05)$ in the sample participants' responses about their roles in the light of knowledge economy due to gender, college, years of experience, educational degree and university?

To answer this question, means and standard deviations of the participants' responses about the instrument in the light of the variables of this study, and that were as the following:

- Gender and college variables: t-test was used and the result was as they are presented in table (6).

Table 6. T-Test Results of the Differences in the Means of the Teacher Roles in the Light of Knowledge Economy Due to Gender and College Variables

\begin{tabular}{|c|c|c|c|c|c|c|c|c|c|}
\hline & \multicolumn{4}{|c|}{ Gender } & \multicolumn{5}{|c|}{ College } \\
\hline & $\mathbf{M}$ & SD! & $\begin{array}{c}\text { Accounted- } \\
\mathbf{T} \\
\end{array}$ & $\begin{array}{c}\text { Significance } \\
\text { level }\end{array}$ & & $\mathbf{M}$ & SD & Accounted- T & $\begin{array}{c}\text { Significance } \\
\text { level }\end{array}$ \\
\hline \multirow{3}{*}{$\begin{array}{r}\text { Male } \\
\text { Female }\end{array}$} & 2.70 & 0.266 & 2.35 & $* 0.019$ & Scientific & 2.736 & 0.255 & 0.024 & $* 0.981$ \\
\hline & & & & & & & & & \\
\hline & 2.78 & 0.203 & & & Literary & 2.737 & 0.230 & & \\
\hline
\end{tabular}

*At significance level $(\propto \leq 0.05)$ 
Table (6) demonstrates that there were statistically significant differences due to gender and college variables in favor of females; it also shows that no statistically significant differences due to college variable were found.

- Years of experience, educational degree and university variables; means and were measured and One Way Analysis of Variance was conducted as it is explained in table (7).

Table 7. The Results of One - Way Analysis of Variance that Related to the Differences in the Means of Faculty Members' Roles in the Light of Knowledge Economy Due to Years of Experience, Educational Degree and University Variables

\begin{tabular}{|c|c|c|c|c|c|c|c|c|c|c|c|c|}
\hline \multirow[t]{2}{*}{$\begin{array}{c}\text { Years of } \\
\text { experience }\end{array}$} & \multicolumn{2}{|c|}{$1-5$ years } & \multicolumn{2}{|c|}{ 5-10 years } & \multicolumn{2}{|c|}{$10-15$ years } & \multicolumn{2}{|c|}{$\begin{array}{c}\text { More than } 15 \\
\text { years }\end{array}$} & & & \multirow[t]{2}{*}{ F- value } & \multirow[t]{2}{*}{$\begin{array}{c}\begin{array}{c}\text { Significance } \\
\text { level }\end{array} \\
\end{array}$} \\
\hline & $\mathbf{M}$ & SD & $\mathbf{M}$ & SD & $\mathbf{M}$ & SD & M & SD & $\mathbf{M}$ & SD & & \\
\hline & 2.73 & 0.277 & 2.69 & 0.224 & 2.74 & 0.233 & 2.77 & 0.249 & & & 0,983 & 0,402 \\
\hline \multirow[t]{2}{*}{$\begin{array}{c}\text { Educational } \\
\text { degree }\end{array}$} & \multicolumn{2}{|c|}{ Teacher } & \multicolumn{2}{|c|}{$\begin{array}{l}\text { Assistant } \\
\text { Professor }\end{array}$} & \multicolumn{2}{|c|}{$\begin{array}{l}\text { Associate } \\
\text { Professor }\end{array}$} & \multicolumn{2}{|c|}{ Professor } & \multicolumn{2}{|c|}{ Lecturer } & & \\
\hline & 2.70 & 0.222 & 2.77 & 0.277 & 2.67 & 0.25 & 2.71 & 0.28 & 2.75 & 0.208 & 1.012 & 0,402 \\
\hline \multirow[t]{2}{*}{ University } & \multicolumn{2}{|c|}{ Jerusalem } & \multicolumn{2}{|c|}{ Hebron } & \multicolumn{2}{|c|}{ Bier Ziet } & \multicolumn{2}{|c|}{ Bethlehem } & & & & \\
\hline & 2.73 & 0,204 & 2.64 & 0.255 & 2.82 & 0.239 & 2.61 & 0.102 & & & 7.26 & 0,0001 \\
\hline
\end{tabular}

*At significance level $(\alpha \leq 0.05)$

Table (7) demonstrates that there were no statistically significant differences in faculty members' roles due to educational degree and years of experience variables, whereas there were significant differences in the means of university variable. To check these differences, One - Way Analysis of and Scheffe test were performed, they indicated that significant differences in favor of Bier Ziet University were found.

\section{Discussion and Conclusions}

The results revealed that knowledge economy concept from the perspective of faculty members was high, while the roles were moderate. With reference to the information, it was revealed that faculty members have sufficient awareness of knowledge economy concept in the importance of knowledge human capital and believing in their developed abilities further more improving them equally. In addition to thier awareness of the importance of the developed, technical and educational system and the scientific research that has important role in entering into knowledge economy world, they need to link education with teaching more and more and to create knowledge and research and development processes as well as fair distribution of human abilities, that was indicated by (Arabic Knowledge Index, 2015; Jum;a, 2015; connell, 2015)

UNISCO 2015, Abu Al-Humos 2006 and Ahmad 2016 emphasized on the necessity of universities transition to knowledge economy to get effective participation in their entering into knowledge economy age, and the necessity of educational system transition towards knowledge in information and globalization age to enable the teacher to cope with a developed informative environment.

Regarding to roles, information demonstrated that faculty members have developed qualifications and skills in addition to the ability of challenging, innovation and acting as creative leaders. They know that they need more training in working as groups and as researchers in research groups in various specializations. This study agreed with the study of (Abu Al-Humos, 2006; Arab Human Development Report, 2003; Al-Hashmi \& Al-Azawi, 2009) on the necessity of ascertaining the accurate specialization of the professor, Psychological and Pedagogical rehabilitation of teaching.

For the variables of the study, there were differences in the knowledge economy concept due to the variables of the study in favor of (1-5 years) and the Associate Professor and in favor of Bier Ziet University.

Regarding to faculty members' roles, there were differences only in favor of females and Bier Ziet University. This means that knowledge economy concept in faculty members was clear for them as an expression, but they lack training and working on utilizing this expression in their roles in teaching and scientific research and working in developed outstanding and creative groups.

Finally, despite the fact that the Palestinian universities are affected by Israeli occupation, they suffer enormous challenges because of either the political embargo or the limited financial capacity, this study revealed high level of university teacher understanding of knowledge economy concept and moderate degree of his expected roles in the 
light of knowledge economy.

\section{Recommendations}

This study recommends the following:

1. Setting out the criteria of measuring teaching productive that consistent with the criteria of knowledge economy concepts.

2. Linking universities with economic trends whenever possible, that through formulating national plan which limits the vision and milestones of the Palestinian universities according to the knowledge economy vision.

3. Promoting the Palestinian universities to take care of developing faculty members' roles in using knowledge economy concepts in cooperation with Palestinian Ministry of Education under thoughtful plan.

4. Holding definitional seminars and workshops of knowledge economy concepts for the leaders of the Palestinian universities which support faculty members' roles and promote the scientific research, group work, innovation and linking them with practical aspect.

5. Taking use of developed countries experiences regarding to developing faculty member with knowledge economy community inputs.

\section{References}

Abo near, N., Sarhan, K. H., \& Zboon, M. (2011). Concept of knowledge economy and the renewable teachers' roles From the perspective of the secondary schools' teachers in Jordan and its relation with some variables. Derasat Education Sciences, 38(1), 330-343. And Vocational Didactics Areas of Vocational Education Research (pp. 17-43). Springer Science +Business Media.

Abu Al-Humos, N. (2006). Towards Education Policies to Enhance Competitive Knowledge Economy in the Palestinian Areas, Palestinian Economic Policy Research Institute (MAS).

Abu Al-Na'er, Nazier Sarhan, Al-Sarhan, Khalid Ali, Al-Zaboun \& Mohammad Saleem. (2011). Knowledge Economy Concept and Renewable Teachers' roles under it from the Perspective of High School Teachers in Jordan and its Relation with Some Variables. Studies, Educational Science, Files 38, No. 1.

Agham, N., \& Abu Al-Khier, A. (2012). The Reality of Implementing the Processes of Knowledge Administration and its Procedures and Development in Al-Quds Open University. Al-Aqsa University Magazine (Human Sciences Series), 16(1), 30-62.

Ahmad, N. M. (2016). Insuring High Education Quality under Knowledge Community, The Sixth Arab International Conference on Insuring Education Quality, High Institution of Comprehensive Carrers, Darna, Libya.

Al-Hashimi, A., \& Al-Azawi, F. (2009). Knowledge Economy and Building the Teacher. Al-Ein: University Book Center.

Al-momany, Z., Showkeh, N., \& Theyabat, M., (2010). The use of teaching skills based on the knowledge economy of the teachers of the Faculty of Physical Education at Yarmouk University. Assiut Journal of Physical Education Sciences and Arts, 31, 210-185.

Al-Najar, J. H. (2012). Developing Education in the Palestinian Universities Under Knowledge Economy. The Research Magazine of Hebron University, 7(2), 229-254.

Al-Sa'e, N., \& Saed M. (2013). Knowledge Economy Role in Developing Saudi Universities and the Activating Obstacles from Perspective of Sections' Managers. Specialized Educational International Magazine, 2(9).

Arab Knowledge Index (2015). Mohammed bin Rashid Al Maktoum Foundation and the Regional Bureau for Arab States UNDP.

Arabic Human Development (2003). Towards Establishing Knowledge Economy in Arab Countries.

Connell, R. (2015). The knowledge economy and university workers. Australian Universities' Review, 57(2).

Hashimi, A., \& Faeza, M. (2007). The curricula and knowledge economy. Dar Maysra for publishing and distribution, Amman, Jordan.

Hashimi, A., \& Azawi, F. (2009). Knowledge economy and teacher formation. Dar Alkitab Jameei, Ein, UAE. 
Jum'a, M. S. A. A. (2009). Developing Education and its Role in Establishing Knowledge Economy. Faculty of Finance and Administration Science, Taif University. Proposal presented by the First International Conference for Electronic Learning and Distance Learning, The Kingdom of Saudi Arabia, Riyadh..

Khadeeja, L. (2015). Analysis of Algerian Economy to Integrate into Knowledge Economy, Economic and Administrative Researches, No. 18, University of Boumerdas - Algeria.

Malika k., (2015). From knowledge traditional to knowledge economy: positive interludes in Indian higher education. International journal of educational planning \& administration, 5(1), 19-23,

Mohammad, D. M. (2012). The Quality of High and Continuing Education Institutions and the Challenges of Knowledge Community, The Second Arab International Conference on Insuring Education Quality, University of Cairo, Egypt.

Moustafa, Mohand Khazar, Alkielani, Ahmad Mohie Adin. (2011). A Degree of Religion' Teachers Practicing for Teacher's Roles in the Lihjt of Knowledge Economy from Perspective of the Supervisors in Jordan. Damascus University Magazine, 27(3+4) - 2011.

Naser. I., Awajneh, A., \& Sabbah, S. (2016). Degree of the Teachers' Practice of Their Roles and Knowledge Economy Concepts from Their Perspective in Palestine. Journal of Emerging Trends in Educational Research and Policy Studies (JETERAPS) 7(5): 371-382. (C) Scholarlink Research Institute Journals, 2016 (ISSN: 2141-6990). jeteraps.scholarlinkresearch.com.

Nashiri, A. (2014). The quality of teaching performance for the teachers of social and national studies at the intermediate stage in the light of the requirements of the knowledge economy. (unpublished ma thesis) University OF Umm Al-Qura, Saudi Arabia.

Nehme, E. (2016). Planning and Funding the Education in Lebanon: Challenges and Perspectives. International Review of Social Sciences and Humanities, 10(2), 61-70.

Sabah, S., Nasir, I., \& Moustafa, A. (2016). Teacher Understanding of their Roles in the Light of Knowledge Economy from Perspective of Supervisors in Palestine (and suggested perception to activate them). Regional Conference "Preparation of Arabic Teacher Cognitively and Professionally", 29-30 November 2016, Amman Arab University, Amman, Hashemite Kingdom of Jordan.

Sabbah, S. S. M., Naser, I A. S., \& Awajneh, A. M. H. (2016). The Teacher's Roles in Light of Knowledge Economy from the Perspective of the Educational Supervisors' in Palestine. Journal of Education and Practice, 7(26), 89-98.

Salem, M. I. (2014). The Role of Universities In building A knowledge -based Economy In Saudi Arabia. International Business \&Economics Research Journal, 3(5), 1047-1056. https://doi.org/10.19030/iber.v13i5.8771

UNISCO (2015). International Report of Monitoring Education for All, Achievements and Challenges.

World Bank (2008). World Development Indicators: Year in Review. Geneva, World Bank. 